\author{
P. Minissale, V. Magro \& F. M. Raimondo
}

\title{
Why did Acanthus mollis, native to West Mediterranean, become a so relevant artistic and symbolic element arising from ancient Greece?*
}

\begin{abstract}
Minissale, P., Magro, V. \& Raimondo, F. M.: Why did Acanthus mollis, native to West Mediterranean, become a so relevant artistic and symbolic element arising from ancient Greece?. — Bocc. 28: 331-340. 2019. — ISSN: 1120-4060 printed, 2280-3882 online.

In classical antiquity many plant species were a source of inspiration in art and architecture. An emblematic case is Acanthus mollis, a Western Mediterranean species, although many Mediterranean countries Floras are in contradiction with respect to its native distribution. Two subspecies are known: A. mollis subsp. mollis distributed in Italy, France and Croatia, and A. mollis subsp. platyphyllus growing in Morocco, Algeria and Tunisia. In other Mediterranean countries it should be an introduced taxon, such as in Greece and Turkey where the native species is A. spinosus. Although the maximum spread of the Acanthus leaf in architecture occurred in Roman times, the Corinthian capital was born in Greece, portraying A. mollis. Among the earliest examples we remember the Doric Temple of Apollo Epicurius at Bassae in Peloponnese, built in 450-425 BC. probably by Ictino, the Tholos at Epidaurus (360-330 BC.), characterized by Doric columns in the exterior, while the inner colonnade consists of 14 Corinthian columns. The leaf carved in the stone is unequivocally A. mollis. The invention of the Corinthian capital is attributed, without certain proof, both to Callimaco and Ictino, which operated in Athens and in the Peloponnese. As this species was not present as native in Greece at that time, it was seen and designed taking inspiration from some place in Sicily or Magna Greece or from cultivated plants originating in those areas. The first examples of this capital fall into areas of Doric ethnicity. A city founded by this ethnic group that had intense cultural exchanges with the mother country was Syracuse, where A. mollis is widespread. This city seems to have played an important role in the the genesis of this architectural element, which is an evidence of cultural influences implemented in the motherland starting from the colonies become autonomous.
\end{abstract}

Key words: botany and art, cultural heritage, Mediterranean plants.

\section{Introduction}

In classical antiquity many plant species were a source of inspiration in art and architecture (Caneva \& Kumbaric 2010). An emblematic case is Acanthus mollis L. and to a

\footnotetext{
*Resulting from the merging of two posters by Minissale and Magro \& Raimondo presented at the International Symposium "Botany at the intersection of Nature, Culture, Art and Science", Selinunte, 2830 June 2018.
} 
lesser extent $A$. spinosus L., both Mediterranean species used in antiquity by Greeks and Romans and later by other Mediterranean peoples above all as architectural frieze carved on capitals. A. mollis also has a remarkable ornamental value and therefore since ancient times it has probably been the object of cultivation and diffusion in other Mediterranean regions, today in the world (GISD 2018).

The aim of the present research is to understand with a biogeographical approach, combined with historical data, which could be the motivations that led to stylize the acanthus shape for the first time in areas where A. mollis, the most represented species of the genus, was not present in the native flora.

For this purpose, it is necessary to reconstruct the native distribution of the Mediterranean species of the genus Acanthus L. This genus is composed of 20 species distributed in Africa, southern Europe, southern Asia, and Australasia (McDade \& al. 2005; Iamonico \& Peruzzi 2018); in the Mediterranean area there are A. mollis subsp. mollis (Fig. 1), A. mollis subsp. platyphyllus Murb., A. spinosus (Fig. 2) and A. balcanicus Heywood \& I. B. K. Richardson (Fig. 3).

\section{Materials and methods}

The research on the distribution of Acanthus species is based on literature material such as floras and checklists of all European and Mediterranean countries, herbarium consultations and personal distribution data. The distributive data are compared with the ancient historical sources related to key moments of displacements of peoples, in particular the Greeks and the Romans.

\section{Historical framework}

Although the maximum spread of the Acanthus leaf in architecture occurred in Roman times, the Corinthian capital seems to be born in Greece (Billot 1993), but through a long process concerning its stylization on the carved stone. Among the earliest examples many authors (Billot 1993, Kelly 1995, Loth 2014, Thodis 2018) remember the Doric Temple of Apollo Epicurius at Bassae in Peloponnese, built in 450-425 BC. probably by Ictino. Gros (1993) is very critical about this interpretation. As this author reminds us, the architectural formalization of the Corinthian capital takes place through the work of Vitruvius De Architectura. This author, lived in the second half of the first century BC, indicated in Callimachus (sculptor and architect operating during Vth century BC) the creator of the aforementioned capital; but probably his affirmation, inserted in a legendary context, only wants to ennoble its origins Inspiration would be drawn by a basket covered by a roof tile and layng on a Corintihian girl's grave by her nurse. Being placed on an acanthus root it got leaves wrapping the basket (Locatelli 2016). Anyway, Gros (1993) believes that the first, supposedly, Corinthian capital of Bassae has nothing to do with those of later centuries as the acanthus leaf is very different from the typical one and barely recognizable as such (Fig. 4). It should also be kept in mind that of this single capital, which had a particular meaning with regard to its location inside the temple (Thodis 2018), there remain only 


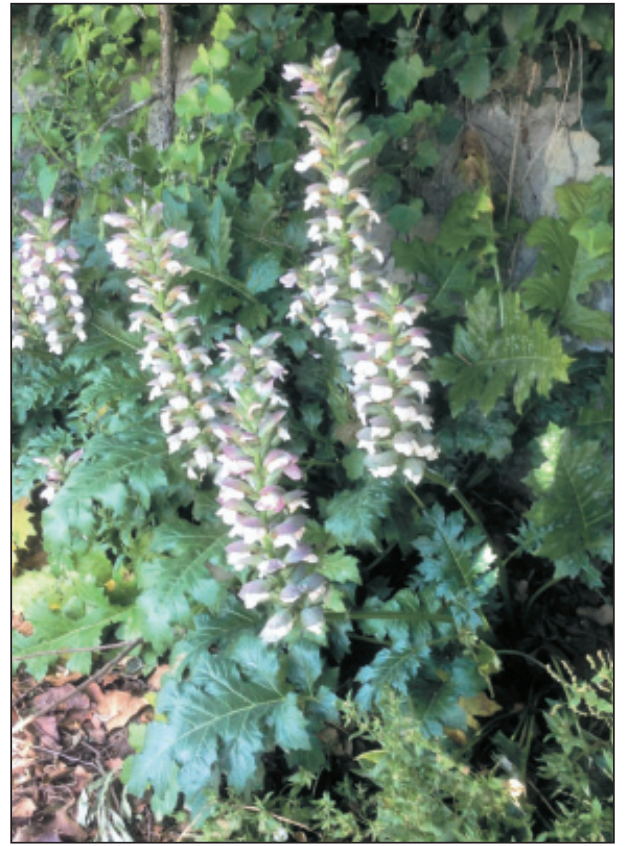

Fig.1. Acanthus mollis in flower to Mount Erice (N.W. Sicily). (Photo F.M. Raimondo, June 2018).

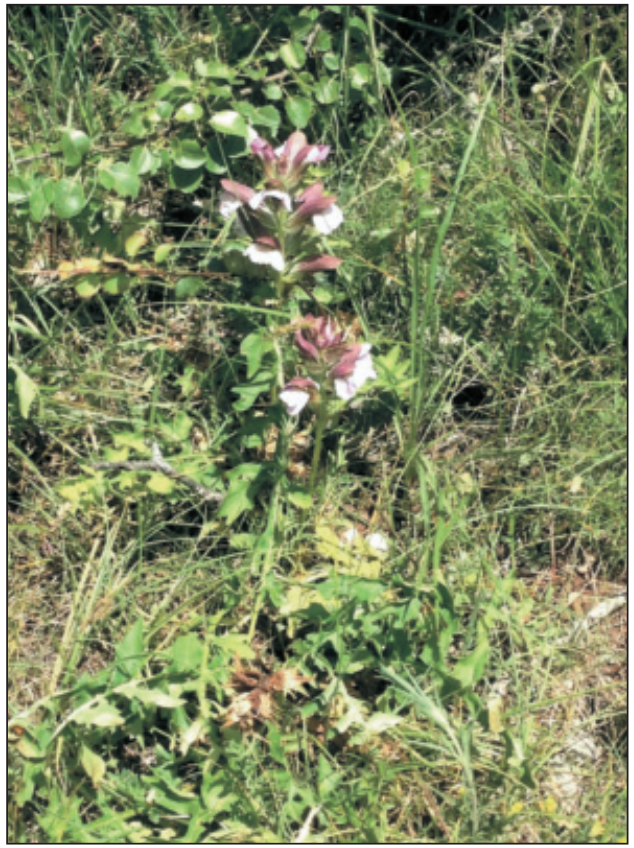

Fig. 2. A. spinosus in flower, from his natural habitat in Albania (Photo F.M. Raimondo, June 2016).

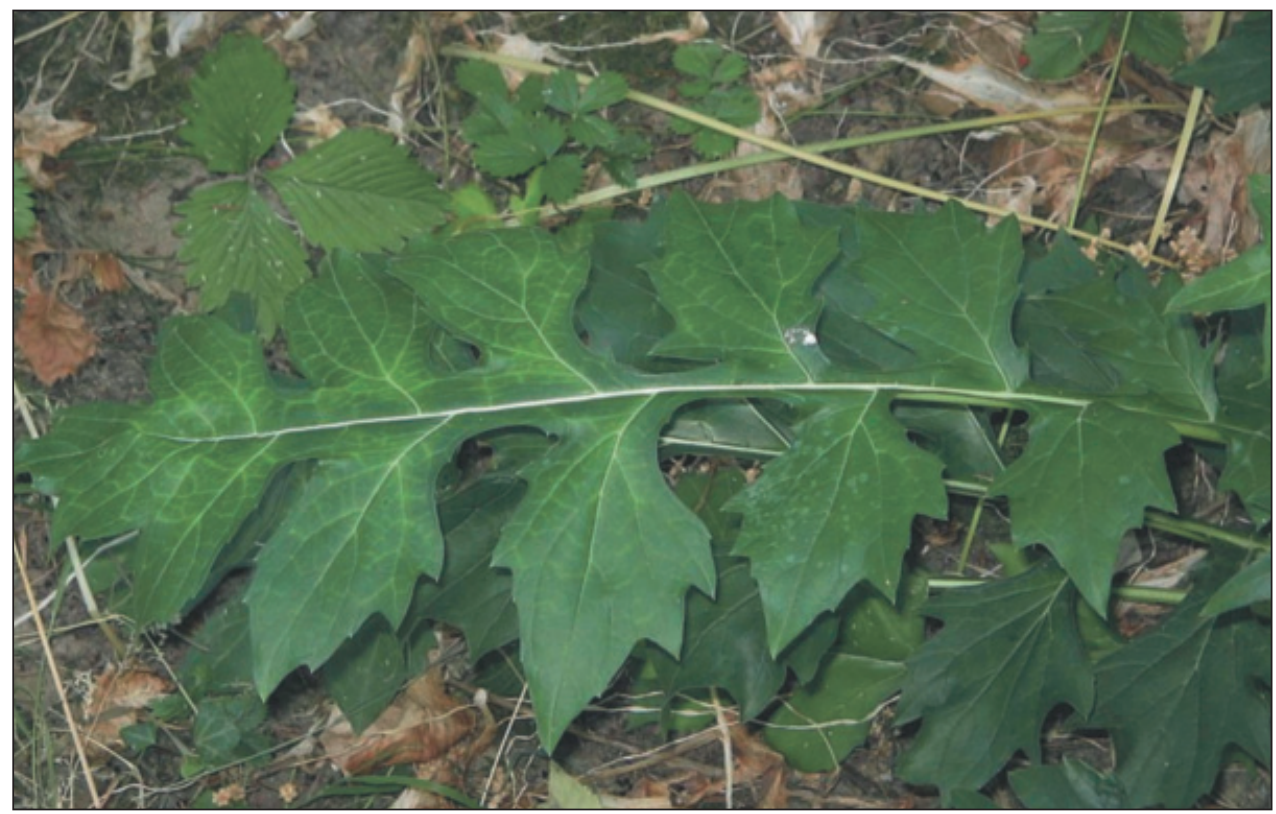

Fig. 3. Acanthus balcanicus: particular of leaves (from Wikimedia Commons, the free media repository). 
fragments, now in National Archaeological Museum of Athens, and a drawing made at the time of the discovery in 1811 (Loth 2014). This first appearance at Bassae of the acanthus leaf as decoration not only occurs on a capital but also on other architectural elements of the temple, such as simas and acroteria. Similar ornaments occur also in the temple of Poseidon at Sounion built about 440 BC. Billot (1993), recognizes at Sounion the form of A. spinosus but she admits that the shape is very stylized so it could also be other real or imaginary plant. The decoration with acanthus on the acroteria appears to the Parthenon of Athens and here the leaves are much more similar to those of $A$. mollis (Fig. 5a). Similar friezes are reported to the Heraion of Argos (Fig. 5b) and in Magna Graecia to Caulonia and Crotone temple of Hera Lacinia, at the Tholos of Epidaurus and at the Tholos of Delphi (Billot 1993), here with very realistic A. mollis friezes (Fig. 5c). The Tholos of Epidaurus, monument built in 360-330 BC., is also characterized by Doric columns in the exterior, while the inner colonnade consists of 14 Corinthian columns. The leaf carved in the stone is unequivocally A. mollis as you can see in the Archaeological Museum of Epidaurus where is showed a Corinthian capital unearthed below the foundations of the Tholos temple (Fig. 6).

The maximum development of the use of acanthus will take place in Roman times but always in connection with the Greek civilization; it must be remembered that since the end of the third century BC the Roman civilization undergoes a profound Hellenization especially with the fall in the Roman hands of the great cities of Magna Graecia and Sicily such as Taranto and Syracuse.

The decorative aspects of the Greek world were much appreciated and contacts with Athens were established. Artistic studios of this city were also installed in Rome (Sauron 1993) starting from 150 BC. In the same period and following, in the age of Augustus, the acanthus leaf will be a fundamental decorative element both for the Corinthian capital that will be formalized by Vitruvius and in other decorations as the extraordinary example of the Ara Pacis (13-9 BC) in Rome (Caneva 2010; Rossi 2016; Sauron 2018), where acanthus supports the architrave and it, in all its variations, will always be recognizable as Acanthus mollis species. Roman Art used acanthus not only in the decoration of the Corinthian capital but in the creation of friezes and pilaster strips, too. Because of its great decorative effect it was preferred in the decoration of the great columned streets ("cardus maximus" in Palmira, Syria, III century BC, "cardus maximus" in Gerasa, Jordan, III century BC) (Rossi 2016).

\section{Results and Discussion}

Defining the native distribution of Acanthus mollis is problematic as, probably, since ancient times it has been diffused from the original sites in other localities of the Mediterranean basin. The indications of the Mediterranean countries Floras and the databases are sometimes inaccurate and in contradiction with respect to its native distribution. Two subspecies are known: A. mollis L. subsp. mollis distributed in Italy (Pignatti 1982, 2018), but in the northernmost regions and Sardinia it is considered an alien species (Ballelli \& Pedrotti 2009; Puddu \& al. 2016); south France and Corse, and A. mollis subsp. platyphyllus Murb. growing in Morocco (Fennane \& Ibn Tattou 2005), Algeria (Quézel \& 


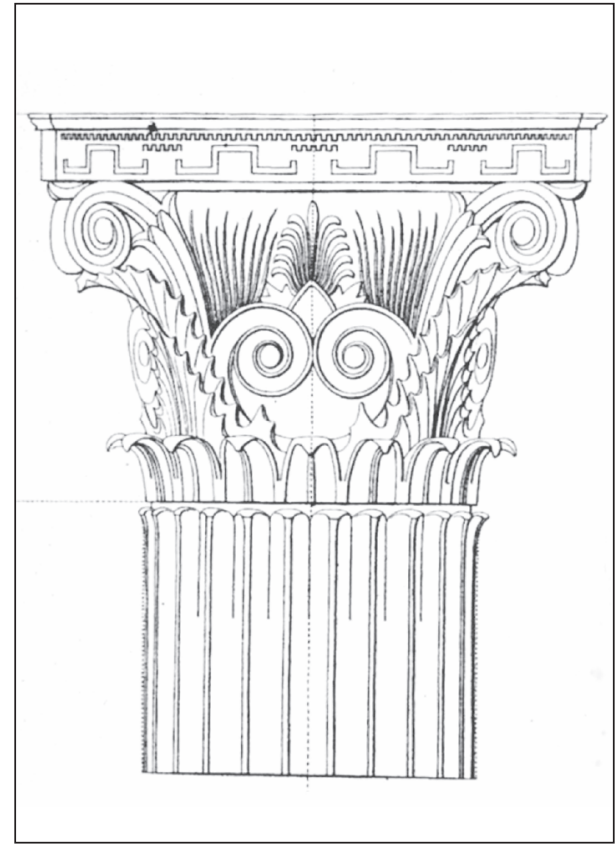

Fig. 4. Drawing of the Corinthian Capital of the Temple of Apollo Epicurius made by J.M. von Mauch for the German edition of the original work by Charles Normand (1819). The drawing is based on field notes and sketches of fragments by the archaeologist Haller von Hallerstein, highlighted during his excavation campaign carried out in Greece, at the site of Bassae (Peloponnese), between 1811 and 1812.

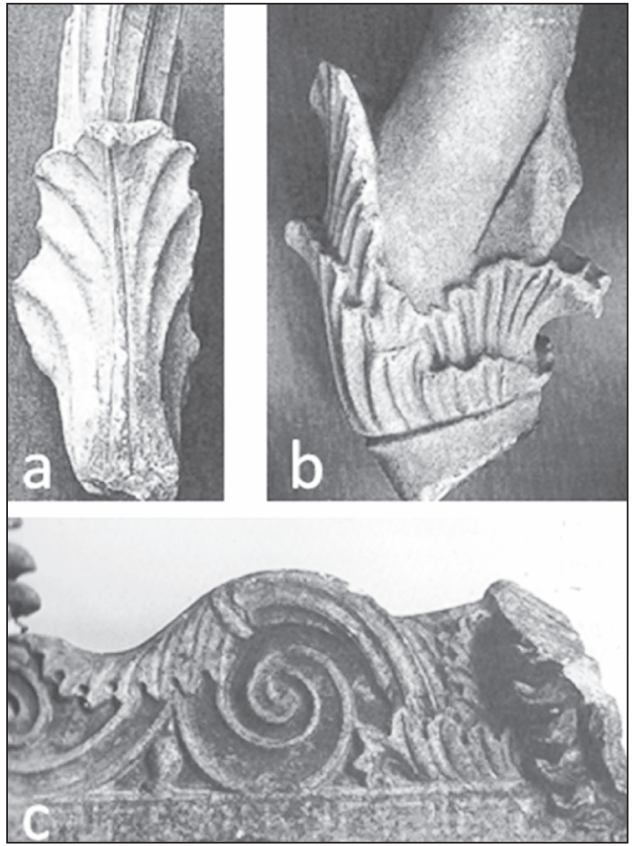

Fig. 5. Acanthus leaves in some ancient Greek monuments (from Billot 1993).

a. Athens; Parthenon, basal fragment of the central acroteria (Acropolis Museum - Athens).

b. Argos Heraion, classic temple, basal fragment of the central acroteria (National Museum Athens).

c. Delphi, Tholos little sima (Archaeological Museum - Delphi.

Santa 1963), Tunisia (Pottier-Alapetite1981), Lybia (El Gadhi 1983) and south Spain (Valdés Castrillón \& al. 1987). In other Mediterranean countries it should be an introduced taxon (Malcuit 1939; Barcelò 1980; Della \& Iatrou 1995; Castroviejo 2001), such as in Greece (Arianoutsou \& al. 2010; Dimopoulos \& al. 2013, 2016) and Turkey (Davis 1984) where the native species is $A$. spinosus L. Also for these species is difficult to know the original distribution. A. spinosus is known in the Mediterranean and in south-eastern Europe (Italy, Croatia, Albania, Greece, Bulgaria, Crete, East Aegean islands), the Asiatic Turkey as well as in Algeria, but it is native probably only in East Mediterranean.

As this species was not present as native in Greece at that time, it was seen and designed taking inspiration from some place in Sicily or Magna Graecia or from cultivated plants originating in those areas. The first examples of this capital fall into areas of Doric ethnicity. A city founded by this ethnic group that had intense cultural exchanges with the mother country was Syracuse, where A. mollis is widespread (Minissale \& al. 2015). From this city, probably, the acanthus was brought to Dalmatia. Today it is in fact present almost 


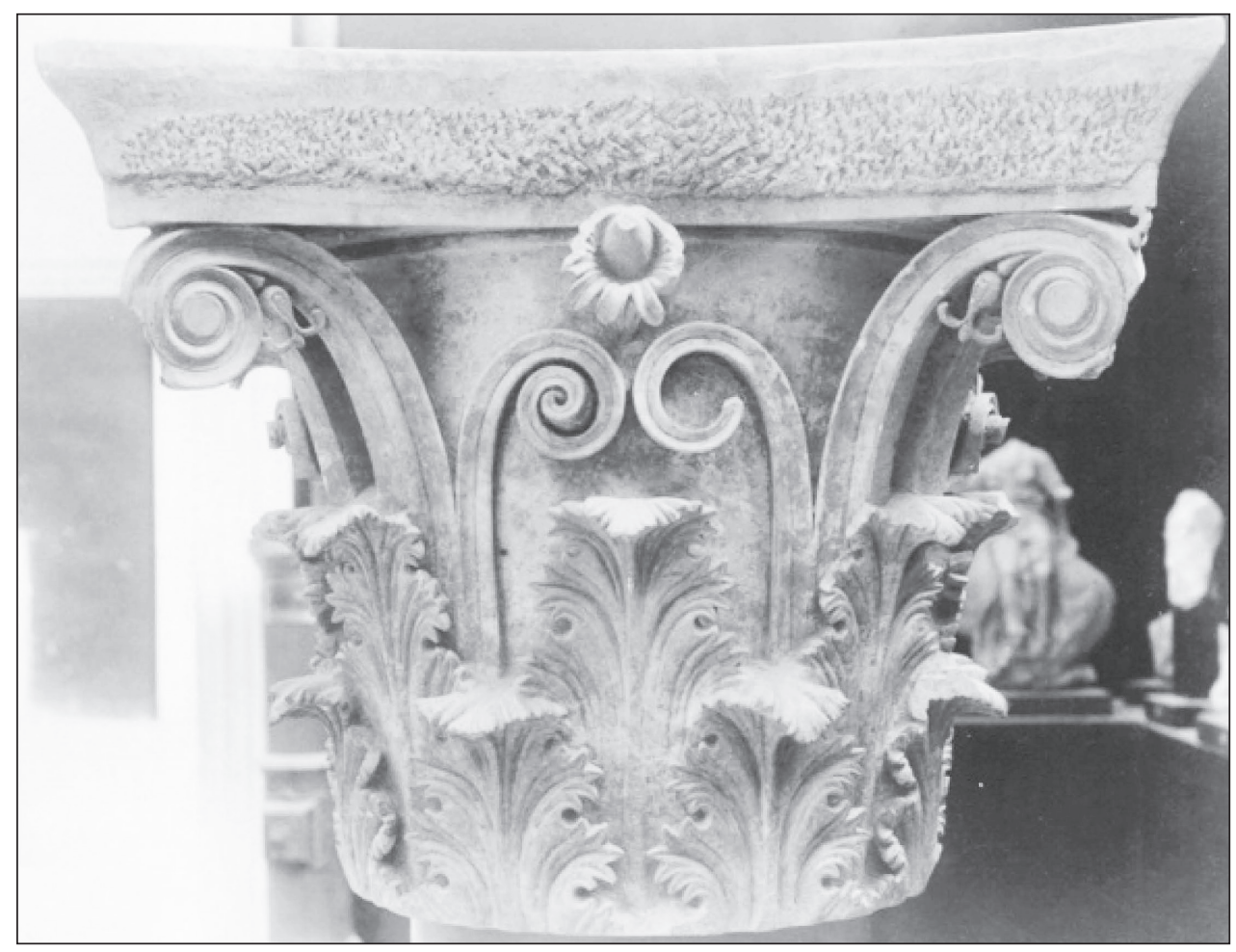

Fig. 6. Corinthian capital from the tholos of Epidaurus (Argolis, Greece) clearly inspired by Acanthus mollis [380-375 BC. Archaeological site of Epidaurus] (from Wikimedia Commons, the free media repository).

exclusively in the Adriatic islands (Nikolić 2015) which were Syracusan colonies or in very close areas. In particular, they were Issa (today Vis Island) and the subcolonies of Lumbarda near Korkyra Melaina (Korčula Island), Tragyrion (Trogir), Epetion (Stobreč) founded from third to second century BC (Lombardo 1993). It also occurs in the nearby Pharos (Hvar Island) founded in 386 BC by Greek settlers from Island of Paros, but allied to Issa. It is surprising the overlap of the presence of the acanthus which in Dalmatia is rare, with the islands affected by the Greek colonization coming from Syracuse (Fig. 7). This circumstance proves, or at least the clue is highly realistic, that acanthus was a relevant species, perhaps also ornamental. It should be noted that Lissa is also the only Dalmatian locality of another species present in Greece and Syracuse surroundings, Salvia fruticosa Mill. (Radosavljević \& al. 2015, 2019), also this probably was transported by the Greeks of Syracuse.

There are no clues so clear for other places, for example of Greece, but it is possible that from Syracuse or from other Greek colonies the acanthus has been made known in the motherland and, representing a much more appreciable species of the native $A$. spinosus, has become a source of artistic inspiration. 


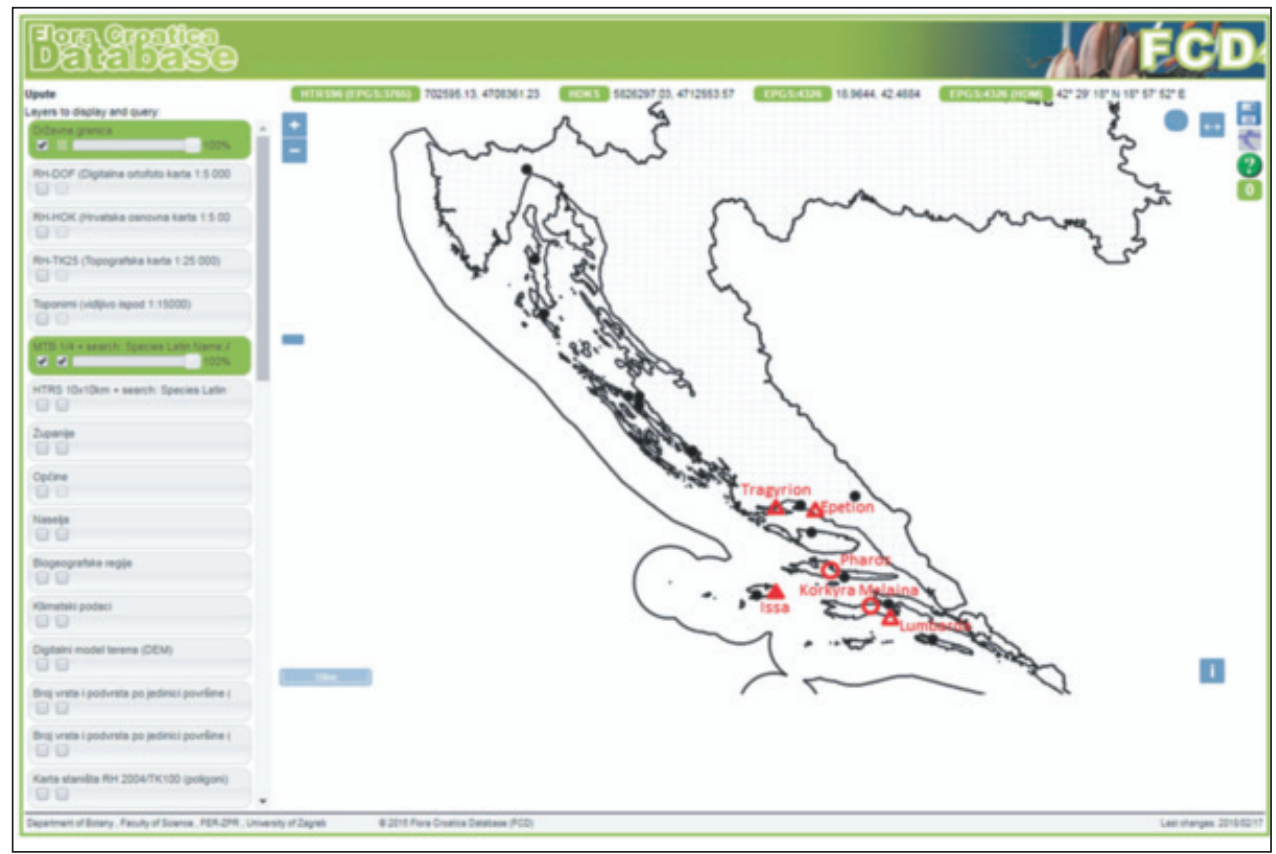

Fig. 7. Acanthus mollis distribution in Croatia (black dots) from Flora Croatica Database (http://hirc.botanic.hr/fcd) and the colonies founded by Syracuse. Issa (today Vis, Lissa in Italian) was the first in 390 B.C., the others are sub-colonies founded by Issa (Tragyrion, Epetion, Lumbarda) or other Greek colonies interacting with Issa (Pharos, Korkyra Melaina).

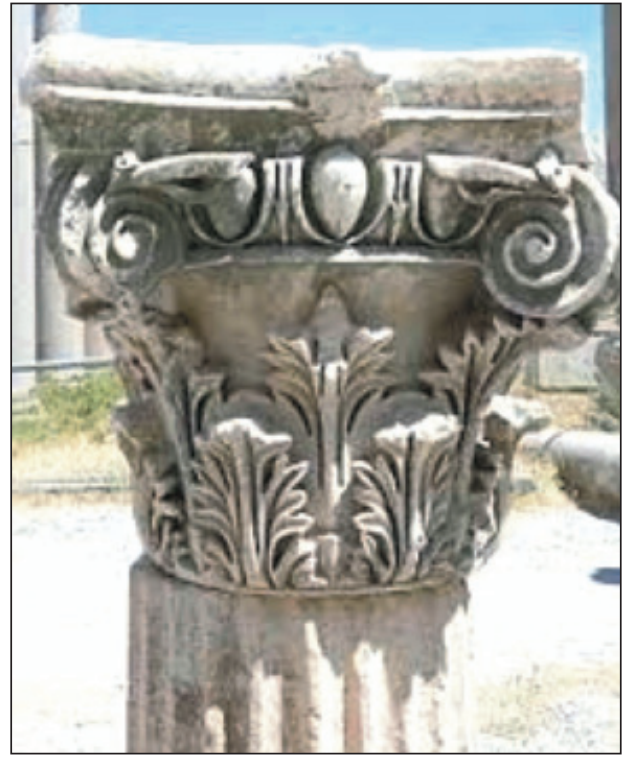

Fig. 8. Corinthian capital - probably inspired by Acanthus spinosus or by A. dalmaticus - from Ephesus (Smyrne, Turkey) [I-II Century a.C.] (from Wikimedia Commons, the free media repository). 
But why was the acanthus in particular chosen? Was it just for the peculiar leaf morphology or for the plant symbolism in classical antiquity? In this regard, the acanthus symbolizes both resurrection and regeneration; in addition, as a perennial herbaceous plant cyclically subject to dry in the summer season and come back to vegetate since the next winter starting a new cycle - it is ideally suited for being interpreted in art and architecture. Therefore, the biological form (hemicriptophyte) of the Acanthus species is the basis of its symbolism and its stylistic success.

But the frenetic activity of the Greek navigators remains fundamental and the consequent contaminations and cultural exchanges between colonies and motherland, contaminations that will then be absorbed and greatly developed later by the Roman civilization.

\section{Conclusion}

Contrary to common interpretations on the possibility that the Corinthian capital may be inspired by several Mediterranean species of Acanthus, what is just discussed opens the way in excluding or minimizing this possibility. The historical, biological and phytogeographic considerations reported, the symbolism of the plant and in particular the cultural exchanges between motherland and Magna Graecia, on the one hand, constitute the cause and effect of the anthropogenic spread of $A$. mollis in the rest of the Mediterranean area of Greek and Roman influence, on the other, of its own decorative and artistic value. All these elements allow us to affirm that the Corinthian capital, originally inspired by A. mollis (Fig. 1) - an easily propagated and cultivated plant and among the most decorative species - may have been inspired, subsequently, also by A. spinosus (Fig. 2) or ever more by A. balcanicus (Fig. 3 ); the latter - native to the Balkan peninsula, up to Dalmatia - is now also cultivated in many European and American gardens. In this different view, the cases of the capitals of the Greek Temple of Apollo Epicurius (Fig. 5) and of the columned street ("cardus maximus") of Ephesus (Fig. 8) appear very expressive and would support the thesis of the congeneric multi-specificity, of the inspirational model of the Corinthian capital.

\section{Funding}

Research partially funded by Annual Research Plan 2016-18 of Dept. Biological Geological Environmental Sciences, University of Catania (grants n. 22722132113).

\section{References}

Arianoutsou, M., Bazos, I., Delipetrou, P., Kokkoris, Y. 2010: The alien flora of Greece: taxonomy, life traits and habitat preferences. - Biol. Inv. 12(10): 3525-3549. https://doi.org/10.1007/s10530-010-9749-0

Ballelli, S. \& Pedrotti, F. 2009: Exotic species of the Marches region Central Italy) and their distribution in different natural vegetation types. - Contr. Bot. 44: 37-47.

Barcelò, F. B. 1980: Flora de Mallorca, 4. - Palma.

Billot, F. M. 1993: L'apparition de l'acanthe dans le décor des toits du monde grec. - Pp. 39-74 in: L'acanthe dans la sculpture monumentale de la renaissance à l'antiquité, Actes du Colloque international (Paris 1990). - Paris. 
Caneva, G. 2010: The Augustus Botanical Code: AraPacis: Speaking to the People through the Images of Nature. - Roma.

— \& Kumbaric, A. 2010: Plants in the ancient artistic representations as a tool of communication and a cultural message. - Proceedings of 4th International Congress on "Science and Technology for the Safeguard of Cultural Heritage in the Mediterranean Basin", Cairo (Egypt) 6th-8th December 2009, 1.

Castroviejo, S. (ed.) 2001. Flora Iberica, 14. - Madrid.

Conti, F., Abbate, G., Alessandrini, A. \& Blasi, C. (eds) 2005: An annotated Checklist of the Italian vascular flora. - Roma.

Davis, P. H. 1984: Flora of Turkey and the East Aegean Islands, 7. - Edinburg.

Della, A. \& Iatrou, G. 1995: New Plant Records from Cyprus. - Kew Bull. 50(2): 387-396. https://doi.org/10.2307/4110645

Dimopoulos, P., Raus, Th., Bergmeier, E., Constantinidis, Th., Iatrou, G., Kokkini, S., Strid, A., Tzanoudakis, D. 2013: Vascular plants of Greece: An annotated checklist. - Englera 31: 1-372. https://doi.org/10.3372/wi.46.46303

$-, \ldots,-,-, \ldots,-,-,-2016$ : Vascular plants of Greece - an annotated checklist. Supplement. - Willdenowia 46: 301-347.

El-Gadi, A. 1983: Flora of Libya, 90-100. - Tripoli.

Fennane, M. \& Ibn Tattou, M. 2005: Flore vasculaire du Maroc. Inventaire et chorologie [1]. Trav. Inst. Sci. Univ. Mohammed V, Sér. Bot., 37: 1-483.

Global Invasive Species Database 2018: Species profile: Acanthus mollis. http://www.iucngisd.org/gisd/species.php?sc=1663 [Last Accessed 26/09/2018].

Gros, P. 1993: Situation stylistique et chronologique du chapiteau Corinthien de Vitruve. - Pp. $27-$ 37 in: L'acanthe dans la sculpture monumentale de la renaissance à l'antiquité, Actes du Colloque international (Paris 1990). - Paris.

Iamonico, D. \& Peruzzi, L. 2018: Lectotypification of the Linnaean name Acanthus spinosus (Acanthaceae). - Phytotaxa 62: 11-12. https://doi.org/10.11646/phytotaxa.62.1.3

Kelly, N. 1995: The archaic temple of Apollo at Bassai. Correspondences to the classical temple. Hesperia 64(2): 227-277. https://doi.org/10.2307/148056

Locatelli, D. 2016: La tarda classicità. - Pp. 378-380 in: Zuffi, S. (ed.), L'antica Grecia, 2. - Milano.

Lombardo, M. 1993: Lo psefisma di Lumbarda: note critiche e questioni esegetiche. - Hesperìa: studi sulla grecità di occidente, 3: 161-187.

Loth, C. 2014: The Temple of Apollo Epicurius at Bassae and its Orders. - Institute of Classical Classical Architecture \& Art - https://www.classicist.org/articles/classical-comments-the-temple-of-apollo-epicurius-at-bassae-and-its-orders/ [Last Accessed 10/10/2018]

Malcuit, G. 1939 : Notes sur la répartition en Corse de l'Acanthus mollis L. et du Lilium bulbiferum L. var. croceum (Chaix) Ducomm. - Monde Pl. 5(235): 3- 4.

McDade, L. A., Daniel, T. F., Kiel, C. A. \& Vollesen, K. 2005: Phylogenetic relationships among Acantheae (Acanthaceae): major lineages present contrasting patterns of molecular evolution and morphological differentiation. - Syst. Bot. 30: 834-862. https://doi.org/10.1600/036364405775097734

Minissale, P., Trigilia, A., Brogna, F. \& Sciandrello, S. 2016: Plants and vegetation in the archaeological park of Neapolis of Syracuse (Sicily-Italy). A management effort but also an opportunity for a better enjoyment of the site. - Conserv. Manag. Archaeolog. Sites 17: 340-369. https://doi.org/10.1080/13505033.2016.1175906

Nikolić, T. (ed.) 2015. Flora Croatica Database (http://hirc.botanic.hr/fcd). Faculty of Science, University of Zagreb [Last Accessed 13/06/2018]. 
Norman, C. 1819: Nouveau parallèle des ordres d'architecture des Grecs, des Romains, et des auteurs modernes, dessiné et gravé au trait par Charles Normand, architecte, ancien pensionnaire à l'Académie de France à Rome. - Paris.

Pignatti, S. 1982: Flora d'Italia, 2. - Bologna.

- 2018: Flora d'Italia, 3. - Milano.

Pottier-Alapetite, G. 1981: Flore de la Tunisie, 2. - Tunis.

Puddu, S., Podda, L., Mayoral, O., Delage, A., Hugot, L., Petit, Y. \& Bacchetta, G. 2016 : Comparative Analysis of the Alien Vascular Flora of Sardinia and Corsica. - Not. Bot. Hort. Agrobot. Cluj-Napoca 44(2): 337-346. https://doi.org/10.15835/nbha44210491

Quézel, P. \& Santa, S. 1963: Nouvelle flore de l'Algérie et des régions désertiques méridionales, 2. - Paris.

Radosavljević, I., Satovic, Z. \& Libe, Z. 2015: Causes and consequences of contrasting genetic structure in sympatrically growing and closely related species. - AoB PLANTS 7: plv106. https://doi.org/10.1093/aobpla/plv106

—, Bogdanović, S., Celep, F., Filipović, M., Satovic, Z., Surina, B. \& Liber, Z. 2019: Morphological, genetic and epigenetic aspects of homoploid hybridization between Salvia officinalis L. and Salvia fruticosa Mill. - Sci. Reports 9: 3276. https://doi.org/10.1038/s41598-019-40080-0

Rossi, A. 2016: La prima età imperiale. Da Augusto all'età Flavia. - Pp. 36-37 in: Zuffi, S. (ed.), L'antica Roma, 4. - Milano.

Sauron, G. 1993. La promotion apollinienne de l'acanthe et la definition d'une estétique classique à l'époque d'Auguste. - Pp. 75-97 in: L'acanthe dans la sculpture monumentale de la renaissance à l'antiquité, Actes du Colloque international (Paris 1990).- Paris.

Sauron, G. 2018: La storia vegetalizzata. Il duplice messaggio dell'Ara Pacis. - Milano.

Thodis, A. 2017: On the Corinthian Column at the Temple of Apollo Epikourios at Bassae. - Awol, The Ancient World Online 1: 1-65.

Valdés Castrillón, B., Talavera Lozano, S. \& Fernandez-Galiano, E. (eds) 1987: Flora Vascular de Andalucía Occidental, 2. - Barcelona.

Addresses of the authors:

Pietro Minissale ${ }^{1}$, Vincenzo Magro ${ }^{2} \&$ Francesco. Maria Raimondo ${ }^{2}$,

${ }^{1}$ Department of Biological, Geological and Environmental Sciences, University of Catania, Via Antonino Longo 19, 95125 - Catania, Italy. E-mail: p.minissale@unict.it

${ }^{2}$ PLANTA/Research, Documentation and Training Center, Piazza Cairoli 11, 90123

- Palermo, Italy. 